\title{
Cigányok/romák pasztorációja
}

\author{
Az egyházak társadalmi szerepvállalása
}

\author{
OLÁH DEZSŐ ${ }^{1}$
}

\begin{abstract}
ABSZTRAKT
Ifjúkoromban arra lettem figyelmes, hogy abban a kis Nógrád megyei faluban, ahol éltem, a cigányok nagy része már nem jár szentmisére és szakít a római katolikus vallással. Ez a tendencia ma is tart, s ezt tapasztalom Pest megyében élve, napjainkban is. Vajon mi lehet ennek a szakadásnak az oka? A választ a váci egyházmegyében eltöltött húszéves hittanári múltam, valamint eddigi empirikus szociológiai kutatásaim segítségével kerestem. Követett-e el hibát a papság, hogy cigányok és nem cigányok tömegesen hagyták s hagyják el az egyházakat? Személyesen szerettem volna hallani a választ, maguktól az érintettektôl. Így a váci megyéspüspök engedélyével római katolikus civil teológusként szolgálati helyükön, plébániájukon kerestem meg a történelmi egyházak lelkipásztorait, hogy kérdéseket tegyek fel nekik a cigány néppel kapcsolatban.
\end{abstract}

KULCSSZAVAK: isten, egyház, cigányság

\section{ABSTRACT}

\section{Pastoral care for the Gypsies/Romas Societal engagement of the Churches}

In my adolescence, I noticed that in my small hometown village of Nógrád County, the majority of the Romani don't attend mass and sever their ties with Roman Catholic religion. This tendency remains to this very day, and I continue to experience the same thing where I now live in Pest County. What could be the reason for this separation? I set out to find the answer with the help of twenty years of experience as a divinity teacher and my previous empirical sociology research. Is the clergy to be blamed for the large numbers of Gypsies and non-Gypsies leaving the fold? I wanted to personally find an answer to the question from the concerned parties. Therefore, at the permission of the bishop of the Diocese of Vác, as a Roman Catholic civilian theologian, I visited the pastors of the Historical Churches at the various offices and parishes to ask them questions about the Romani.

KEYWORDS: God, Church, Romani

\footnotetext{
${ }^{1}$ Váci egyházmegye, teológus, e-mail: jilokris@invitel.hu
} 


\section{TEMATIKUS TANULMÁNYOK - Társadalmi mobilitás és segítői tevékenység}

\section{Bevezetés}

A rendszerváltás, a gazdasági átalakulás a szakképzetlen, aluliskolázott rétegeket, így a cigányságot érte el elsőként. A munkanélküliek átképzésére indított számtalan program sem volt képes a munkaerőpiacon jól konvertálható tudáshoz, tartós álláshoz juttatni a résztvevőket. Az ország válságtérségeiben (az egykori szocialista nagyipar övezeteiben) a cigány családok szűkös megélhetését a rendszerváltást követően elsősorban segélyekkel biztosították. A cigány nép integrációja jelen korunk egyik legfontosabb és legsürgősebb ügye. Noha a romák döntő többsége ínséges körülmények között él, meggyőződésem szerint legalább annyira fontos a harmonikus társadalmi együttélés megteremtése, mint az éhezés felszámolása. E folyamat előmozdításában minden valóságos társadalmi erőre, így az előző rendszer által rákényszerített béklyóitól megszabadult egyházakra is kiemelkedő szerep hárul. Sajátos tevékenységükkel, nélkülözhetetlen feladatvállalásaikkal egyre nagyobb és látványos eredményekben is megmutatkozó hatást gyakorolnak. A család és az állam mellett a történelem folyamán az egyház is mindig ember- és társadalomformáló erő volt, és nézetünk szerint napjainkban is az. Meggyőződésem szerint a sikeres lelkigondozói tevékenység révén a cigányok és a nem cigányok közötti társadalmi konfliktusok oldódhatnak. Másrészt a cigány közösség identitását megőrizve saját kultúrájával, értékeivel, hagyományaival együtt, a társadalom szerves és megbecsült része lehet. Ezért 2010 és 2019 között empirikus kutatásokat végeztem a váci egyházmegyében, mert komoly érdeklődésem tárgyává vált, hogy megismerjem a lelkipásztorok életútját, valamint feltárjam a lelkipásztorok meglévő ismereteit a cigányokról. Kíváncsi voltam arra is, hogy a lelkipásztorok miként vélekednek a cigányság hitvilágáról és véleményük szerint a cigányok egyházba történő integrációja hogyan alakul. Jelen tanulmány tárgya viszont nem az empirikus kutatási eredmények prezentálása, hanem egy elméleti struktúrán keresztül bepillantást adni arról, hogy az egyház hogyan kezd hozzá a cigányok/romák pasztorálásához, illetve hogyan tekint a társadalom perifériájára szorult cigányokra. Ez az azért is érdekes, mert a cigány/roma társadalmi tér mind fogalmilag, mind bonyolultságát tekintve rendkívül ingoványos talaj. Nyelvi, etnikai, kulturális elemzéseket tárgyalok, de a helyzet nem lesz egyértelmúbb. Ami egyre inkább egyértelmű, az a helyzet zavarossága. A tanulmány első felének a célja ennek a zavarosságnak a bemutatása, ahol az egyház ténylegesen is elkezdi pasztorációs szolgálatát.

Mint ahogyan más tudományágak, úgy a teológia sem képes arra, hogy emberi közösségekről egy minden tudományos szakterületre kiterjedő átfogó elemző társadalmi képet adjon. Ez különösen igaz akkor, ha a történelmi egyházak hazánk legmagasabb számú nemzetiségét kívánják lelkigondozói tevékenységben részesíteni. Az egyház a cigányság felé indított sikeres küldetésének első lépése az, hogy a cigány/roma nemzetiség körében a társadalomtudományok által feltárt eddigi eredményeket és ismereteket, mint például a cigánynép nyelvét, kultúráját, identitását 


\section{TEMATIKUS TANULMÁNYOK - Társadalmi mobilitás és segítői tevékenység}

figyelembe vegye, és azokat beépítse lelkipásztori programjába. A több évszázados lemaradását pótolva, örvendetes, hogy a társadalomtudományi kutatások mellett, most az egyház is szeretné mélyebben megismerni azt a réteget, akiket eddig, csupán érintőlegesen, de szisztematikusan sohasem vett missziójának célkeresztjébe. Az egyház ezzel a tevékenységével növelheti, az egyébként 1930-2011 között nagymértében csökkenő tendenciát mutató híveinek számát (KSH 2014).

\section{A roma/cigány kisebbség mint pasztorációs tér}

Írásomban a történelmi egyházak cigánypasztorációs tevékenységét tárgyalom. Amennyiben egyszerűen csak a kifejezést, a cigánypasztorációt mint szóösszetételt nézzük, akkor rögön megjelenik benne a „cigány” szó. Első megközelítésben tehát arról van szó, hogy az alábbiakban tárgyalásra kerülő pasztorációs tevékenység a cigány/roma kisebbség körében zajlik. Sőt maga a pasztoráció „tárgya” is a cigány kisebbség. Ennek következtében tehát nem hagyhatjuk „érintetlenül” a cigány kisebbséget, vagyis foglalkoznunk kell a témával. A cigány/roma kisebbséghez tartozó csoportok meghatározása legalább három szempont szerint lehetséges. Egyfelől napjaink nyugati kultúrájában ennek kellene a modális meghatározási módnak lenni - az adott roma csoportot saját maga elnevezése szerint jelölhetjük. Másfelől az sem lényegtelen, hogy a különböző roma csoportok miként jelölik egymást. Végül rendkívül lényeges az is, hogy a nem roma (többségi) társadalom hogyan nevezi meg az egyes roma csoportokat. Tehát az egyes roma csoportoknak, törzseknek legalább háromféle megnevezése lehetséges. A három elnevezés ráadásul nem szükségszerűen ugyanaz. Logikailag lehetséges, hogy egy adott csoportot a három nézőpont három különböző névvel jelöl. Ennek következtében már önmagában ez a csoportközi helyzet olyan bizonytalanságokat hordoz magában, amelyekkel bizony a romológiai szakirodalomnak is meg kell birkóznia. A romológiai szakirodalom ma már rendkívül bőséges. A magam részéről ehelyütt nem is kívánok ennek tárgyalásába részletesen belemenni, hiszen a jelen írás szempontjából például nem is igazán lényeges, hogy a mai cigány népesség honnan származik. Most néhány olyan, a romológiai szakirodalom által is tárgyalt kérdésre szeretnék rámutatni, amelyek jól jelzik azokat a bizonytalanságokat, amelyek közt az egyházak pasztorációs tevékenysége zajlik. Nézzük elsőként a cigányság nyelvi meghatározásának problematikáját. Rendkívül lényeges kérdésről van szó, hiszen a nyelv jelenti azt az elsődleges kategorizációs keretet, amely segítségünkre van a körülöttünk lévő világban való eligazodás során (Nietzsche 1992). 


\section{TEMATIKUS TANULMÁNYOK - Társadalmi mobilitás és segítői tevékenység}

\section{Nyelvi meghatározatlanság, Shib thaj le rom}

A tudományos kutatásokban a roma és a cigány kifejezéseket, Európában így Magyarországon is felváltva szoktuk használni. ${ }^{2}$ „A hétköznapi kommunikációban gyakran okoz problémát e népcsoport megnevezése, nagy a bizonytalanság, hogy mikor, mely közösségben melyiket használjuk, nehogy megsértsünk bárkit is, ha rosszul használjuk a megnevezéseket. Fontos megjegyeznünk, hogy a magyarországi három fő cigány csoport mindegyike, ahogy több más dologban, úgy ebben is megkülönbözteti magát a másiktól. Ennek eredményeképpen a magyarországi cigányság jelentős része - pl. az oláh cigányok romának, a romungrók és a beások többsége - cigánynak nevezi magát, nem „romának”, mindazok ellenére, hogy a közéletben és a politikai szóhasználatban egyre nagyobb teret nyer a „roma” elnevezés. A romungrók és a beások számára tehát a cigány az a tágabb, általánosabb fogalom, amelybe beletartozik az a csoport is, aki magát romának nevezi. A különböző roma szervezetek a londoni, 1971-ben megtartott Első Roma Világkongresszusra hivatkoznak, ahol a másmás cigány közösséget képviselő jelenlévők egyetértésben fogadták el, hogy a világ összes cigány emberének a közös és hivatalos elnevezése legyen a rom szó többes számú alakja, azaz a roma forma. (A romaniban csak az adott etnikai alcsoporthoz tartozókra utal, a „rom” szó jelentése „férfi”, „férj”, míg a szó többes számú alakja a „roma” jelentése „férfiak, illetve emberek.” A kifejezés nőnemű párja a „romnji” „roma nő, asszony,” „feleség”). Bár megoszlik a vélemény a terminusok használatát illetően, hisz sokan nem tekintik egymás szinonimájának a cigány vagy roma szót, így nem is fogadják el a roma szó kizárólagos használatát, ezért az egyre jobban terjedő cigány/roma egyenrangú használata mindenki számára megoldást jelenthet." (Orsós 2015: 153-154) Látnunk kell, hogy a romák nyelvükben sem egységesek. Amennyiben a nyelvhasználat alapján szeretnénk a különböző romacsoportokat meghatározni, akkor legalább három nagyobb csoportot kell elkülönítenünk. „A magyarországi cigányok három nagy nyelvi csoporthoz tartoznak. Ezek: a magyarul beszélő magyar cigányok, romungrók alkotják (akik magukat magyar cigánynak, zenész cigánynak vagy muzsikus cigánynak mondják), a két nyelven, magyarul és cigányul beszélő oláh cigányok (akik magukat romának, romnak mondják) és a két nyelven, magyarul és románul beszélő román cigányok (akik magukat beásnak mondják)." (Kemény - Janky 2003: 64-77) Ez a három nagyobb nyelvi csoport több kisebb alcsoportra oszlik. A romani nyelvnek sokáig nem volt írásbelisége. Azok a különböző tudósok, akik megpróbálták átírni vagy lejegyezni a beszélt nyelvet, gyak-

\footnotetext{
${ }^{2}$ Ha már a tanulmány fogalomhasználatánál tartunk, akkor ezen a helyen jelezném azt is, hogy tanulmányomban a „cigányság” szóhasználat mögött elsősorban fogalmazásból adódó megfontolások állnak. Ahogy a következő sorokban is láthatjuk majd, nem beszélhetünk egységes cigányságról, cigány népről. Erre példa az is, hogy az utóbbi néhány évben megjelentek a hajléktalan emberek között a cigány származású emberek is. Azaz a cigányságnak már nincs olyan megtartó és összetartó ereje, mint volt néhány évvel a rendszerváltás után.
} 


\section{TEMATIKUS TANULMÁNYOK - Társadalmi mobilitás és segítői tevékenység}

ran saját fonetikai konvencióikhoz folyamodtak, ám mivel a nyelvek igen változatosak a helyesírás és a kiejtés közötti megfelelés szempontjából, az így keletkezett átírások között sok az eltérés. Magyarországon - ha eltekintünk a 19. század közepének, végének ez irányú eredményeitől, a nyelv leírására 1943-ban történt az első kísérlet: a Csenki testvérek a Kodály évkönyvben, illetve a Bazsarózsa 99 cigány népdal című munkájukban nemzetközi normákra és pontos nyelvészeti lejegyzésekre törekedtek. Ez a folyamat az 1980-as évek második felétől válik intenzívebbé. A magyarországi romani dialektusainak összegyűjtésére elsőként Erdős Kamill vállalkozott a 20. század derekán. Az általa csoportokba szedett 13 nyelvjárásból azonban feltehetőleg már nem él mindegyik, hiszen a vegyes házasságok és a nyelvvesztés miatt mára több eltűnhetett közülük (Lakatos 2015). Közel húszéves romani nyelv oktatói és egyházi szakfordítói munkám során tapasztaltam, hogy a formális regiszterek, amelyek a közélethez, és az oktatáshoz lennének szükségesek, hiányoznak a romani nyelv alapszókészletéből. „A magyarországi cigány nyelvek hosszú időn keresztül semmiféle intézményes támogatottságot nem élveztek, így e nyelvek oktatási, szakmai, közigazgatási, jogi stb. regiszterei ki sem épülhettek. A mindenkori állam nem teremtette meg a feltételeket a beás és a romani nyelv kodifikációjához, következésképpen a formális szó- és írásbeliség kialakulásához és elsajátíttatásához sem." (Bartha 2015: 34)

\section{A roma/cigány népcsoport nemzetiségi és etnikai identitása}

Magyarországon a 2011. évi CLXXIX. törvény rendelkezik a nemzetiségeket megillető jogokról. A törvény szerint 13 nemzetiség van Magyarországon. 2012. január 1-je előtt 12 nemzeti kisebbségről és egy etnikai kisebbségről (cigányság) rendelkezett a törvény. A 2011-es népszámlálási adatok szerint több mint 650 ezer magyar állampolgár tagja valamelyik nemzetiségnek (KSH 2014). Noha a törvény biztosítja a nemzetiségek jogait, sokan mégsem vállalják fel, hogy valamelyik nemzetiséghez tartoznak (elsősorban a cigányok). Köszönhető ez az asszimilációs folyamatoknak (ahogy az előzőekben is jeleztem, a nyelvcsere kapcsán is láthattuk). Sokan inkább nem vallják be, hogy a cigány kisebbséghez tartoznak. Így „védekeznek” az előítéletekkel szemben. Ennek következtében valószínűleg a népszámlálási adatoknál magasabb a valamely nemzetiséghez tartozók aránya. Témánk szempontjából érdemes a nemzetiségi törvényből a nemzetiség meghatározását ehelyütt felidézni. A meghatározás a törvény I. fejezetének Alapvető rendelkezései között található. „1. § (1) E törvény értelmében nemzetiség minden olyan - Magyarország területén legalább egy évszázada honos - népcsoport, amely az állam lakossága körében számszerű kisebbségben van, a lakosság többi részétől saját nyelve, kultúrája és hagyományai különböztetik meg, egyben olyan összetartozás-tudatról tesz bizonyságot, amely mindezek megőrzésére, történelmileg kialakult közösségeik érdekeinek kifejezésé- 


\section{TEMATIKUS TANULMÁNYOK - Társadalmi mobilitás és segítői tevékenység}

re és védelmére irányul." (Jogtár 2011) Azaz a meghatározás során a törvényalkotó egyfelől a Magyarország területén történő jelenlét történetiségéhez köti a nemzetiség meghatározását (múltja van). Másfelől az is lényeges, hogy a nemzetiségnek kisebb létszámban kell jelen lennie, mint a lakosság többségének. Ebből a szempontból a nemzetiség egyúttal - legalábbis első megközelítésben számbeli értelemben kisebbség is. Ezen túl lényeges, hogy legyen saját nyelve, kultúrája és hagyománya egy nemzetiségnek. Továbbá, hogy legyen „összetartozás-tudat” a nemzetiség tagjai között. Ebből a szempontból a roma nemzetiség egyre nehezebb helyzetben van, hiszen ahogy a nyelv esetében az előző részben láthattuk, számos nyelvileg is elkülönülő csoportról beszélhetünk a cigányok esetében. Tehát azt is lényeges kiemelnünk, hogy a törvényben olvasható „nemzetiség” fogalom lényegesen több elemet tartalmaz, mint a nyelv (még akkor is, ha a nyelv kiemelt helyen van a meghatározásban). Természetesen a társadalom többsége, pláne a cigányok többsége nem rendelkezik se jogi, se társadalomtudományos végzettséggel. Nagy valószínűséggel többségük nem is tudja felsorolni a fenti definíció elemeit. Ráadásul, ahogy az előzőekben láthattuk, a cigányok körében jelentős nyelvcsere zajlott és zajlik ma is, amelynek következtében jóval többen beszélik a magyar nyelvet (is), mint valamelyik cigány nyelvet. Azaz csak és kizárólag nyelv alapján nem lehetséges az identifikálás. Ezért is kérdezett rá tudományos kutatásaiban Kemény István és kollégái a nemzetiséghez tartozásra. Kemény, Janky, Lengyel a cigányokkal kapcsolatos kutatásainak egyik nagy kérdése volt, hogy egyáltalán „ki a cigány?”. A válasz egyáltalán nem triviális. Olyannyira, hogy egész vita bontakozott ki a kérdés kapcsán. Anélkül, hogy ezt a vitát részleteiben bemutatnánk és körüljárnánk, mindössze jeleznénk, hogy a témában a kutatók logikailag a következők közül választhatnak. Ezek szerint cigány az,

- akit a környezete cigánynak tart,

- aki önmagát cigánynak tartja,

- akit a környezete is cigánynak tart és saját magára is cigányként tekint (Kemény - Janky - Lengyel 2004).

Kemény István és munkatársai abból indultak ki, hogy a környezet által cigánynak tekintett embereket keresték fel. „Le kell szögeznünk, hogy az a cigány ember, aki cigánynak tartja magát, népszámlálás idején nem feltétlenül vallja magát cigány nemzetiségűnek. Igen sok ember van, aki magát cigánynak és magyarnak vagy magyarnak és cigánynak tartja, nemzetiségi hovatartozását illetően azonban nem cigánynak, hanem magyarnak, vagy magyar cigánynak vallja magát." (Kemény - Janky - Lengyel 2004: 42) 2004-es kötet révén az 1990-es és a 2001-es népszámlálási adatokat hozzák fel példaként a szerzők. Az 1990-es népszámlálás alkalmával 143 ezer, míg a 2001-es népszámlálás alkalmával már 190 ezer ember vallotta magát cigánynak. Viszont az iskolastatisztikák alapján készült becslésekből 1990-re 440-450 


\section{TEMATIKUS TANULMÁNYOK - Társadalmi mobilitás és segítői tevékenység}

ezer, míg 2001-re 550-570 ezer cigány embert becsültek (Kemény - Janky - 2003: 64-77).

Érdemes megidézni Csepeli György identitásról szóló gondolatait. Csepeli különbséget tesz személyes és társadalmi identitás között. Az előbbi esetében a következőről van szó. „Az identitásélmény funkciója a saját élet elmúlását jelző pszichológiai feldolgozása. Azonosságtudata révén a személy felülkerekedik a változásokon, és megteremti a maga alapvető változatlanságának fikcióját, melyen belül aztán maga szabja meg, hogy mit ismer el megváltozottnak." (Csepeli 1997: 520) A személyes identitás voltaképpen a (társas) külvilág változékonyságából adódó bizonytalanság, valamint az élet elmúlásával kapcsolatos bizonytalanságra adott válasz. Pozitív személyes identitás révén lehetséges a szimbolikus interakcionista felfogás szerinti társas külvilág okozta bizonytalanság csökkentése. Természetesen a társas külvilág a személyes identitás támogatására is van. Ezt fejezi ki a társadalmi identitás. A pozitív kollektív identitás ugyanúgy pozitív hatással van a bizonytalanság oldására, mint ahogy a pozitív személyes identitás is. Csepeli kiemeli Pataki (1987) nyomán, hogy a „pszichoszociális identitás dilemmái akkor vetődnek fel különös élességgel, ha a személy marginális helyzetbe kerülve egymással versengő önmeghatározások között kénytelen választani." (Csepeli 1997: 522) Ebből a szempontból sem lényegtelen a cigánytelepek újbóli szaporodása, az elkülönülés és a diszkrimináció. Ez az a lélektani bizonytalanság, amelyben az egyház cigánypasztorációs szolgálata nélkülözhetetlen. Az eddig leírtaknak az volt a célja, hogy bemutassam a cigánypasztorációs szolgálat „helyszínét”. Azt a teret, amelyben az egyházak pasztorációs munkája történik. Ez témám esetében a cigányság. Annak ellenére, hogy manapság már sok mindent tudunk a roma kisebbségről, az eddigiek alapján is jól látható, hogy ezek a tudások ellentmondásoktól nem mentesek. Gyakoriak az egymással szöges ellentétben álló gondolatok, adatok. Olyan bizonytalan területről van szó, amely a társadalom tagjainak, a társadalompolitikának, a politikai vezetőknek egyaránt fejtörést okoz. Nem csoda, hiszen roppant bizonytalanság övezi a témát. Még az azzal foglalkozó társadalomkutatók esetében is. A téma összetettségét a világi „hatalmak” egyszerű, hatalmuk megtartása szempontjából történő vágásokkal igyekeznek számukra kezelhető mértékűvé szűkíteni. Ezek a vágások nem, vagy csak nagyon ritkán mutatnak a társadalmi integráció, a tolerancia, a társadalompedagógia, a konfliktuskezelés irányába. Állításom az, hogy az egyházaknak a pasztorációs munka révén a nyers politikai természetű beavatkozásoknál jóval finomabb, célravezetőbb, elegánsabb eszközeik vannak. Ennek az állításomnak az érdekében a következő részben igyekszem bemutatni a pasztorációs küldetést és annak világi hátterét. 


\section{TEMATIKUS TANULMÁNYOK - Társadalmi mobilitás és segítői tevékenység}

\section{A pasztorációs küldetés}

Az egyházi tevékenységek között rendkívüli jelentőségű a pasztoráció.

A pasztoráció szó szerint lelkigondozást jelenet, amely szinonimája a lelkipásztorkodásnak, vagy hívek pasztorálásának, illetve a missziónak. A pasztoráció elé illesztett jelzős szerkezet rámutat arra a sajátos egyházi tevékenységre, amit a pap, lelkipásztor, lelkész, vagy pásztori címeket viselő személy végez. Ez a tevékenység egy adott rétegre vagy rétegekre specializálódik, így beszélhetünk családpasztorációról, ifjúságpasztorációról, munkáspasztorációról, vagy cigánypasztorációról is. Az egyházi személyeknek szakpasztorációt nem kötelező sem végezni, sem elvállalni, ezt civilek is végezhetik. A munka egy önálló döntés, vagy elhívás következménye, mint például az orvosi hivatásnál, ha valaki a számára fontos kutatási területből szakvizsgát kíván tenni, majd később abban aktívan dolgozni is akar. Az egyházban ez a fogalomkör a Jézusi küldetés parancsából fakad. Ahogy Máté evangéliuma ${ }^{3}$ őrzi. A cigánypasztoráció tehát Jézus tanítói, nevelői és pásztori munkájának a folytatása, jelen esetben a cigányok között. A cigánypasztoráció mint rétegpasztoráció a cigányközösségek lelkigondozását és szociális gondoskodását teszi a figyelem és a cselekvés központjába. A pasztorációt mint egyházi kifejezést leginkább a történelmi egyházak használják. Fontos megjegyeznünk, hogy Magyarországon az egyházaknak minősített közösségek között lényeges eltérések vannak tartalmilag és formailag egyaránt. A „pasztoráció” értelmezése során érdemes különbséget tenni a római katolikus és a történelmi protestáns egyházak, így a református és az evangélikus egyházak, valamint a neoprotestáns egyházak között. A történelmi egyházak az ember teljes lényegét érintő üzenet átadására fókuszálnak, míg a kisegyházak szigorúan csak a bibliai alapokra koncentrálódó üzenet átadására törekednek. ${ }^{4} \mathrm{Az}$ előbbi az evangélium átadása mellett az ember szociális körülményeit nemcsak hogy figyelembe veszi, hanem annak alakítását kifejezetten küldetésének, céljának rendeli alá. Vannak, akik azért választják a papi vagy szerzetesi hivatást, mert egy adott területtel, azaz szakpasztorációval szeretnének foglalkozni. Mások viszont az általános papi, lelkipásztori munkájuk közben kérnek lehetőséget rétegpasztorációs tevékenységre is. Az engedélyt mindig a helyi megyéspüspök, tartományfőnök vagy házfőnök adja meg. Ebben az esetben viszont a pasztoráció súlyának, kihívásainak megfelelően az eddig végzett feladatkör alól fel kell menteni a személyt, hogy teljes energiájával a szakpasztorációra tudjon koncentrálni. A katolikus egyház intézményrendszere történetiségéből kifolyólag önmagában is hordozza a szakpasztorációs lehetőségeket. Amíg az egyházmegyés papok egy város vagy falu közösségének plébániájáról vezetik a közösségeket, addig a szerzetes közösségek, így a betegápoló,

\footnotetext{
${ }^{3}$ „Én kaptam minden hatalmat mennyben és a földön. Menjetek tehát, tegyetek tanítványommá minden népet, kereszteljétek meg őket az Atya és a Fiú és Szentlélek nevében, és tanítsátok őket mindannak megtartására, amit parancsoltam nektek. Íme, én veletek vagyok mindennap, a világ végéig." (Mt 28:17)

${ }^{4}$ A II. Vatikáni Zsinat Dokumentumai 2000. Budapest: Szent István Társulat 266-267, 670.
} 


\section{TEMATIKUS TANULMÁNYOK - Társadalmi mobilitás és segítői tevékenység}

tanító, ifjúságpasztorációval foglalkozó rendek stb. valamilyen specializált területet fednek le. Így a saját területükön a legkiválóbbak a szakpasztorációban.

Mindenekelőtt áll az evangélium hirdetése lehetőség szerint a közösség saját nyelvén. Ez Magyarországon a cigányság esetében részben kivitelezhető, mert 2008-ban a Szent Jeromos Társulat jóváhagyásával megtörtént a szentírás cigány nyelvre való lefordítása. Nemes és kifejezetten hasznos cselekedet lenne, ha a cigánypasztorációt végző személyek alap-, vagy középfokú jártasságot szereznének a cigány nyelvből. Ez a törekvés jelenleg még kezdeti stádiumban van. Két-három olyan elhivatott lelkipásztor van, akik minimum 20-30 éve végeznek missziós munkát a cigányok között, és többnyire folyékonyan beszélnek cigányul. Magyarországon hagyománya van az évente megrendezendő csatkai, a mátraverebélyi, valamint a máriapócsi cigány búcsúknak. Ezeknek a búcsúknak a megszervezése, lebonyolítása is pasztorációs tevékenység. A cigányok körében fontos szerepet tölt be a leginkább egyházi ünnepnapokhoz kötődő karitatív adományok kiosztása, amely szintén komoly logisztikai munkát igényel. Az aktív munkás hétköznapok pedig sok szellemi programot igyekeznek nyújtani minden korosztálynak. A gyermekeknek tanodákkal, felzárkóztató és rekreációs programokkal igyekeznek segíteni a pasztorációban tevékenykedő személyek. A felnőtteket a specifikus katekézis mellett szakmai és célirányos munkahelyi beszélgetésekkel, tréningekkel és átképzésekkel segítik. Léteznek szelektált programok is, amelyek csak nőknek indítanak speciális gyermeknevelési, mentálhigiénés képzést, vagy fiataloknak tartanak drogprevenciós előadásokat. A test, az értelem és a lelki nevelés mellett fontos területe a pasztorációnak a roma kultúra, identitás és hagyományok őrzése, ápolása is. A saját kultúrával rendelkező népcsoportnak a hagyományok ápolása, pl. a cigányzene és -tánc gyakorlása mellett a pasztorációt végző személynek arra is törekednie kell, hogy közös liturgikus és kulturális alkalmakat biztosítson a többségi táradalomhoz tartozó személyekkel való együttlétre. Ezzel is lebontva a sztereotípia és a társadalmi elóítéletesség falait egymás iránt.

\section{Cigány pasztoráció Európában}

Az Európába érkező első csoportok (1417) vallási magyarázatokkal indokolták vándorlásukat, Egyiptomból menekült bűnbánó zarándokoknak mondták magukat (Fraser 2006: 288). A területi elvre épülő egyház pasztorációjának hatóköréből minduntalan kicsúsztak a vándorló kompániák. A XV. és XVI. században az átalakuló európai társadalmak kivetették azokat, akik nem asszimilálódtak. Idegeneknek tartották őket, és mint a rend felforgatóit kezdték értelmezni őket. Ilyen közegben hívták össze a tridenti zsinatot (1545-1563). A katolikus és a protestáns egyházak is eretnekeknek tartották a cigányokat. A cigányok pedig igyekeztek megőrizni identitásukat és autonómiájukat, ezért a keresztény társadalmak veszélyforrásként tekin- 


\section{TEMATIKUS TANULMÁNYOK - Társadalmi mobilitás és segítői tevékenység}

tettek rájuk. Tehát ennek alapján sui generis feszültségről beszélhetünk (Fraser 2006).

A fenti megfogalmazás azonban így általánosságban véve nyilvánvalóan egyoldalú. Ugyanis az általános minősítés ellenére a cigányok befogadása és az evangéliumi üzenet közvetítésének szándéka egyetlen korban sem hiányzott az egyházból. Katolikus teológiai fogalomkör szerint, az egyház szent, mert Jézus alapította, de bünös is, mert emberek alkotják. Az ember pedig nem lehet tökéletes. ${ }^{5}$ Az egyház valós arcát azonban még a legsötétebb korszakokban is a szentek hozták létre és váltak annak alkotójává. Létrejött a cigányokkal foglalkozó kongregáció a Madonna del monti kerületben (ez volt a vándorló cigányok számára kijelölt hely). Ezekben az evangélium hirdetésének erejével próbálták megnyerni a cigányokat az evangélium számára. Később, 1680-ban Palermóban templomot kaptak: „Santa Mariava in Egitto” (az Egyiptomba menekülő Szűz) elnevezéssel. A XIX. században főleg nyelvi és antropológiai kérdések álltak a cigányok iránti érdeklődés középpontjában, ez az érdeklődés ugyan csökkentette a távolságot, de a tényleges testvéri befogadás még messze volt. A XX. század rettenetes eseménye a cigány holocaust. A nácik a zsidók mellett a cigányokat is irtották. Máig tisztázatlan az áldozatok száma. A katolikus egyház nevében a II. világháború után a pápák többszörösen elítélték a rémtetteket és megpróbálták biztosítani a cigányokat arról, hogy ők bizony fontosak számukra. Legutóbb Ferenc pápa kért bocsánatot 2019 júniusában Balázsfalván - a konkrétan meg nem nevezett esetekért (Kolozsi 2019). A következőképpen fogalmazott: „Az egyház nevében bocsánatot kérek az Úrtól és tőletek azokért a pillanatokért, amikor a történelem során hátrányosan megkülönböztettünk, bántalmaztunk, vagy elhibázott módon, Káin, és nem Ábel tekintetével pillantottunk rátok, és nem tudtunk elismerni, nem tudtuk értékelni bennetek a sajátosságaitokat." Rendkívül lényeges, hogy a katolikus egyház vezetője hogyan nyilatkozik meg az ilyen társadalmi integrációt érintő kérdésekben. Azért is, mert ennek nem csak közvetlen, de közvetett hatásai is vannak, tekintettel arra is, hogy szervezetszociológiai értelemben az egyház hierarchikusan felépüló nemzetközi intézmény, így a papoknak mindenképpen iránymutatásként szolgál a pápa. Ezért is volt lényeges Ferenc pápának azon üzenete, amelyet a vándorlók és menekültek világnapja alkalmából adott közre, továbbá fontos kiemelnünk Ferenc pápa egy korábbi, a cigányokkal inkább közvetve foglalkozó gondolatát is, amelyet 2018. szeptember 18-20. között a Vatikánban megrendezett konferencián adott közre.

Somogyi Viktória Vatican Newson megjelent Ferenc pápa a xenofóbiáról, a raszszizmusról és a populista nacionalizmusról szóló konferencia résztvevőihez című cikke számol be az Egyházak Ökumenikus Tanácsa és a Keresztény Egységtörekvés Pá-

${ }^{5}$ A II. Vatikáni Zsinat Dokumentumai 2000. Budapest: Szent István Társulat 145-148. 


\section{TEMATIKUS TANULMÁNYOK - Társadalmi mobilitás és segítői tevékenység}

pai Tanácsa által megrendezett konferenciáról. Jelentős rendezvényről van szó. Az egyházi intézményeken kívül a konferencián jelen volt az ENSZ, valamint az Európa Tanács is. A Vatikánban megrendezett konferenciához kapcsolódva a pápa fogadta a résztvevőket, akiknek átnyújtotta előre megírt felszólalását is. A leírt és átadott beszéd középpontjában az intolerancia, a diszkrimináció, a kirekesztés, illetve ezeknek a negatív társadalmi folyamatoknak az elkerülése van. Lényeges kiemelnünk, Ferenc pápa hangsúlyozza, hogy nem maradhatunk közömbösek ezekkel a negatív társadalmi folyamatokkal kapcsolatban. Sőt, azon túl, hogy felhívja a figyelmet ezekre a folyamatokra, kifejezetten kéri is a nevelőket, az iskolai és egyetemi oktatókat az emberekkel való megkülönböztetésmentes kapcsolatok kialakításának tanítására. A kulturális sokszínűség, a más emberekhez való rasszizmusmentes hozzáállás, az élet szentségének tiszteletben tartása, a szeretet és a szolidaritás mind-mind olyan értékek, amelyeket aktívan meg lehet tanítani és meg is lehet tanulni. Ezt kéri a pápa. Ahogy a cikk szerzője fogalmaz: „Krisztusban a tolerancia testvéri szeretetté, gyengédséggé és konkrét szolidaritássá alakul át. Kereszténynek lenni tehát felhívás arra, hogy árral szemben ússzunk, és hogy felismerjük, befogadjuk és szolgáljuk Krisztust testvéreinkben.” (Somogyi 2018). Ferenc pápa sok szempontból úttörő, ám voltak elődei, például VI. Pál pápa.

\section{Pál pápa Poméziában mondott homíliájából}

1965 szeptemberében VI. Pál pápa a II. Vatikáni Zsinat alatt a Pomézia kegyhelyen összegyúlt romákat meglátogatta és korszakalkotó beszédet intézett hozzájuk. A beszéd hosszabb változatát a Ceferino Ház honlapján elolvashatjuk, de témánk szempontjából szükséges egy rövidebb tartalmi összefoglalót közölnünk.

A pápa beszédében azt fogalmazza meg, hogy az egyház anyai szeretettel szereti a romákat és készen áll arra a feladatra, hogy gyermekét segítse és vezesse a földi életben. Felhívja a romák figyelmét arra, hogy az egyházban lévő megkeresztelt tagok egymással testvéri kapcsolatban állnak, akik egyenrangú polgárai az egyházi közösségnek.

Az egyház szerető gondoskodása után a pápa megemlékezik a faji üldöztetés áldozatairól, részvétét és együttérzését fejezi ki az utókor generációjának, cigány társadalmának. A múlt felidézése után a jelenre irányulnak a pápa gondolatai, amelyben nyilvánvalóvá teszi a romák számára is, hogy az egyház tud arról, hogy a romák a társadalom perifériáján élnek. Közli a romákkal, hogy ha szeretnének ottmaradni, maradhatnak, de azért ő mindenkinek felkínálja segítségét és szolgálatait. Tudatosítani kívánja a romákban azt, hogy ők nem az egyház perifériáján, hanem annak a középpontjában vannak. Szó szerint a következőket mondja: „Az egyház szívében vagytok, mert szegények vagytok és segítségnyújtásra, oktatásra, segítségre van 


\section{TEMATIKUS TANULMÁNYOK - Társadalmi mobilitás és segítői tevékenység}

szükségetek; az egyház szereti a szegényeket, a szenvedőket, a kicsinyeket, a kitagadottakat, az elhagyottakat." (Magyar Kurír 2015)

Egy új családról beszél a katolikus egyházfó, amelyben az embernek páratlan méltósága van, amely lehetővé teszi, hogy az ember bölcs, erényes és becsületes legyen. VI. Pál buzdítja a romákat a társadalommal való békés kapcsolatra, ezért türelemre, jóságra és tiszteletre kéri őket. Látható, hogy a pápáktól az előbbiekben megidézett gondolatok igen általánosak. Nem is lehet ez másként, hiszen a katolikus egyház az egész világra kiterjedő intézményrendszer. A pápa ugyanúgy szól egy Indiában élő katolikushoz, mint egy olaszhoz vagy egy mexikói, esetleg egy kongói hívőhöz. Miközben nyilvánvaló, hogy ezek a kultúrák rendkívül különböznek egymástól, ezért aztán az ezeken a helyeken élő embereket is esetenként más eszközökkel kell segíteni. Ezért is fontos bemutatni, hogy a cigányokkal foglalkozó nemzetközi katolikus szervezetek milyen jellegű (lokális) pasztorációs tevékenységet végeznek, így közelebb jutunk a cigánypasztoráció fogalmához és értelmezéséhez.

\section{Cigányokkal foglalkozó nemzetközi katolikus szervezetek hálózata és tevékenységeik}

André Barthelemy - az európai cigány körökben Yoshka és Youschka néven emlegetett - francia katolikus pap cigánykaravánokhoz csatlakozva az 1950-es években, kezdte meg a cigánypasztorációs tevékenységét, amely később a nemzetközi katolikus bizottság ${ }^{6}$ a cigányokért megalapításába torkollt. Ő és a köré csoportosuló keresztény cigányokat segítő értelmiségi kör tevékenységének is köszönhető, hogy alig másfél évtized alatt a cigányok ügye a keresztény közgondolkodásban is nagyobb teret nyert, olvashatjuk az 1992-ben megjelent Cigányország útjain címú könyvében (Barthelemy 1992). A Vatikán is figyelmet szentelt a cigányok lelki gondozásának. 1958-ban XII. Pius megalapította az OASNI (Opera Assistenza Spirituale Nomadi in Italia) szervezetet, amely a nomádok, köztük a cigányok lelki épülését, hitre térítését, illetve abban való megerősítését támogatta. VI. Pál pápa 1965-ben alapította meg a Nomádok és Állandó Lakóhely Nélkül Éloók Titkárságát, majd 1970-ben, amikor a különböző hivatalokat a Püspöki Kongregáció felügyelete alá rendelte, létrehozta az Úton Lévők és Elvándorlók Lelki Gondozásának Pápai Bizottságát (Tanácsát), melyet aztán 1988-ban II. János Pál pápa önállósított, Pastor Bonus néven. E bizottság feladata a légi, közúti s vízi közlekedésben dolgozók és utasaik, a lakóhelyüktől távollévők (kivándorlók, menekültek, zarándokok, vendégmunkások, turisták), valamint a nomádok lelki gondozása, akik közé a vándorcigányok okán a romákat is

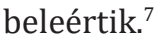

\footnotetext{
${ }^{6}$ Comité Catholique International pour les Tsiganes (CCIT).

${ }^{7}$ Római Dokumentumok XXXIV: Vándorlók és utazók lelki gondozásának pápai tanácsa.
} 


\section{TEMATIKUS TANULMÁNYOK - Társadalmi mobilitás és segítői tevékenység}

A nemzetközi cigánypasztoráció másik kulcsszervezete 1976-ban több, az 1970-es évek elején szervezett informális találkozó után Párizsban jött létre Katolikus Nemzetközi Bizottság a Cigányokért (CCIT) néven. A már említett francia pap, André Barthelemy s egy belga házaspár, Elisa és Léon Tambour hozta létre az európai Youschka Bartolémyt (CCIT) a cigánypasztoráció kibontakoztatására és koordinálására. A bizottság a kezdetektől együtt dolgozott az egyházzal és különleges kapcsolatokat ápol a Vándorlók és Úton lévők Lelkigondozásának Pápai Tanácsával. „A Világiak Pápai Tanácsa által elismert szervezet, amely [...] minden ország papságával baráti együttműködésben munkálkodik. Tevékenységében és éves nemzetközi találkozóin arra törekszik, hogy növelje a keresztény közösségek és egyházak fogékonyságát, érzékenységét a cigányság valós problémái iránt." (TZS 2016) Ezeken a találkozókon az európai cigánypasztorációval foglalkozó nemzeti felelősök és referensek - mintegy száz ember, húsz európai országból - vesznek részt. A CCIT elnöke Claude Dumas atya, aki francia nemzetiségű, cigány származású római katolikus pap. A zsinat nyomdokait követve a Vándorlók és Utazók Lelkigondozásának Pápai Tanácsa 2005. december 8-án kiadta az Irányelvek a Cigánypasztorációban című dokumentumát, amely mérföldkő a cigánypasztorációban. „Összegzi a cigánypasztoráció tapasztalatait”, és ezek alapján „először fogalmazza meg, mi a teendője a befogadó Egyháznak, és mire hívja az Egyház a cigányságot.” (Krómer 2007).

A római katolikus egyház legfőbb feladatai az igehirdetés és a társadalmak közötti béke megteremtése. Értelemszerūen az egyház ez irányú küldetését a Szentírásból vezeti le: „mi békességünk” (Ef.2,14). A béke mint fogalomkör hívőnek és nem hívőnek ugyanazt jelenti. A béke pozitív megfogalmazása szerint olyan egyetemes értékeket és feladatokat jelent, amelynek az alapjai a társadalom értelmi és erkölcsi rendjében találhatók. A béke ezért az emberi személyiség helyes felfogásán alapul. A római katolikus egyház a társadalmak közötti békés együttélés, valamint a cigánypasztoráció alapjait és lényegét a „béke” megteremtésében látja. Szemléletmódját a Hegyi beszédben ${ }^{8}$ elmondottakra alapozza. A CCIT 2010-es konferenciáján egy cigány származású pap, a franciaországi cigánypasztoráció korábbi vezetője, Claude Dumas arra hívta fel a figyelmünket, hogy a schengeni övezet változása felgyorsította a különféle cigány csoportoknál érzékelhető migrációs folyamatot, negatív hatást gyakorol a cigányok világára. A helybeli cigányok és a bevándoroltak között ugyanolyan bizalmatlanság alakul ki, mint bármely más kisebbségben élő etnikumhoz tartozó idegennel szemben. Ugyanezen a konferencián résztvevő magyar főpap, dr. Székely János püspök megerősítette, hogy az egyháznak nincs szándékában asszimilálni a cigányokat, kívánatos integrációjukra tekintettel, mely csakis a tanulás és munkaerőpiaci jelenlét útján képzelhető el, kommunikációra törekszik velük. A konferencián elhangzott, hogy Európában 14 olyan Szalézi közösség van, amely elsődleges fon-

\footnotetext{
${ }^{8}$ Vö. Mt. 5, 1-12.
} 


\section{TEMATIKUS TANULMÁNYOK - Társadalmi mobilitás és segítői tevékenység}

tosságot tulajdonít a cigány fiatalokkal való foglalkozásnak. A szaléziak főként a nevelés területén munkálkodnak. A katolikus egyház cigánypasztorációs munkáját segítik az alábbi közösségek is:

- Nemzetközi Karitász, a Sant’Egidio Közösség;

- Katolikus Nemzetközi Bizottság a Cigányokért (CCIT);

- az Európai Romák és Utazók Fóruma (ERTF) képviselői.

- A Caritas Internationalis a cigányok érdekében végzett segítségnyújtás és kezdeményezések tekintetében Európa különböző országaiban a projektek és tevékenységek sokfélesége jellemzi a Caritast. A közreműködés, beavatkozás leginkább 5 területen jelennek meg:

- kiskorúakkal való foglalkozás az elemi szintű oktatás,

- lakhatás,

- törvényességi kérdések,

- egészségi kérdések,

- munkaerőpiacra való belépés (Ceferino Ház 2010).

A Caritas Europa közös cselekvési programot dolgozott ki („Step in”), melynek az a célja, hogy megelőzze az iskolai tanulmányok idő előtti abbahagyását, hogy szakmai ismeretek megszerzése útján támogassa a társadalmi integrációt (Ceferino Ház 2010). A Sant'Egidio Közösség, a cigányok és a közösség közötti kapcsolat Rómában alakult ki az 1970-es évek vége felé. Ettől kezdődően több olasz és európai városban - ahol a közösség jelen van - került sor kapcsolatfelvételre. A közösség hosszú ideje belefogott egy kulturális, szociális kampányba, mely azt tűzte ki célul, hogy növelje a fogékonyságot a cigánysággal szembeni félelmek és sztereotípiák terjesztésének megállítása ügyében, nevezetesen nyilvános találkozók útján, legújabban pedig egy könyv kiadásával, „Il caso zingari”, mely az olaszországi és európai cigányellenességről szól (Il caso zingari, 2008). Az Európai Romák és Utazók Fóruma, az (ERTF) egy olyan autonóm, nem kormányzati szervezet (NGO), mely pénzügyi és logisztikai téren, valamint a céljait illetően kiemelt partneri viszonyban van az Európa Tanáccsal. Az intézmény megalkotta a „Romák Jogainak Európai Chartáját”, melyhez az Egyetemes Emberi Jogok Deklarációjából és az Egyesült Nemzetek Chartájából vette az inspirációt, majd az elveket a cigányságra és helyzetükre alkalmazta (RomNet 2004). Látnivaló, hogy akár a konkrétumok, akár az inkább „elvi” jellegü kinyilatkoztatások felől haladunk, az egyház cigánypasztorációs gyakorlata jól összefügg azokkal a társadalomtudományos ismeretekkel, amelyek a „cigánypasztorációt” tudományos oldalról érintik. Természetesen nem célom, hogy a „vallási tanokat” tudományos köntösbe bújtassam. 


\section{TEMATIKUS TANULMÁNYOK - Társadalmi mobilitás és segítői tevékenység}

\section{A pasztorációs küldetés világi párhuzamai}

Társadalomtudományos szempontból talán könnyebben érthetők a következő terminusok: tolerancia, társadalompedagógia, cigány-nem cigány együttélés, konfliktusredukció, konfliktusmenedzsment. Voltaképpen az előbbiekben bemutatott és a következőkben is tárgyalt egyházi cigánypasztorációs tevékenységek is éppen ezek köré a fogalmak köré szerveződnek. Természetesen az egyházi megközelítések esetében van még egy különös elem, ez pedig maga a hit. Ezzel együtt - e helyütt ennek az állításnak a bizonyításától eltekintek - az sem hit nélkül való, hogy ha valaki a „világbékében”, a „világbéke megteremtésében” hisz.

Nagyjából azt mondhatjuk, hogy ha véletlenszerűen kiválasztunk egy olyan szociálpszichológiai kötetet, amely a fenti témákkal foglalkozik, akkor szinte mindegyik a kategorizáció jelenségének tárgyalásával kezdődik. Ez természetesen nem független G. W. Allport (1977) korszakos művétől, Az előitélettől, amely olyan témákat tárgyal, amelyek a cigánypasztoráció során is gyakran előkerülnek. Allport könyvének elején, kijelölve annak tárgyát, igyekszik bemutatni az elóítélet szó jelentésének változatait. Elemzése szerint az előítéletek első megközelítésben (az ókorban a praejudicium) olyan eset volt, amelyet megelőző tapasztalat, illetve döntés alapján minősítettek. Olyan ítéletekről van tehát szó, amelyek minősítése a szokások alapján történik. A szó jelentésének következő változataként Allport az angol jelentésváltozatra utal. Ebben az előítélet olyan ítélet, amely előtt ugyan megtörténik a konkrét esetre vonatkozóan a tények összegyűjtése, azonban nem történik meg az összegyüjtött tények alapos vizsgálata, mérlegelése. Tehát az előítéletek olyan ítéletek, amelyek nem vesznek tudomást a tényekről. Allport ennél tovább is megy, amikor a túláltalánosítás jelenségére hívja fel a figyelmet. Azaz nem csak arról van szó, hogy a tényeket vagy nem gyűjti össze, vagy nem dolgozza fel megfelelően az előítéletes emberi elme, hanem arról is, hogy meg is másítja. Mégpedig úgy, hogy azok az „információfeldolgozó" hatalmi szempontjainak megfelelően illeszkedjenek a csoportközi helyzethez. Végül Allport felhívja a figyelmet arra is, hogy az előítéletek nem csak kognitív képződmények. Nem csak információfeldolgozási problémáról van szó az előítéletek esetében, hanem arról is, hogy a hibás információfeldolgozás, illetve annak hiányához emocionális elemek társulnak. Azaz az információfeldolgozás helyébe bizonyos pontokon érzelmi típusú „protézisek” kerülnek. Az előítéleteket pedig leginkább az különbözteti meg a téves ítéletektől, hogy kizárnak minden olyan információt, érvet, amely nem illik az előítélet zárt rendszeréhez (Allport 1977). Ezért is beszél Rokeach (1960) „zárt gondolkodásról”. Allport a New English Dictionaryt idézve az előítéletek következő előzetes meghatározását adja: „Kedvező vagy kedvezőtlen érzés egy személy vagy dolog vonatkozásában, mely megelőzi a tényleges tapasztalatot, illetve nem azon alapul." (Allport: 35) Rendkívül lényeges a cigánypasztoráció szempontjából, hogy az egyház számára minden hívő egyforma, illetve egyformán fontos - függetlenül azoktól a szociológiai meghatározottságoktól, amelyek működésbe 


\section{TEMATIKUS TANULMÁNYOK - Társadalmi mobilitás és segítői tevékenység}

hozzák az előítéleteket (lényeges, hogy Isten előtt mindenki egyenlő). A cigányokkal kapcsolatos elóítéletek esetében az etnikai hovatartozás jelenti azt a szociológiai kategorizációt, amely elindítja a negatív társadalmi folyamatokat. Allport a következő definícióval szolgál. „Az etnikai előítélet hibás és rugalmatlan általánosításon alapuló ellenszenv. Megmaradhat az érzések szintjén, de kifejezésre juthat a viselkedésben. Irányulhat egy-egy csoport egésze, de egyetlen egyén ellen is, azon az alapon, hogy az illető a szóban forgó csoport tagja." (Allport 1977: 40) Tehát az előítélet nem csak kognitív, hanem érzelmi modalitású jelenség is. Ebből a szempontból is lényeges, hogy az egyház kifejezetten a dogma szerint olyan érzelmi, transzcendentális tartalmakat közvetít, amelyek az előítéletek ellen lépnek fel. ${ }^{9} \mathrm{Az}$ is lényeges, hogy az egyház nem kis részt vállal abban az oktatási tevékenységben, amely egyfelől tudásszociológiai értelemben segít az ítéletalkotáshoz szükséges ismeretek öszszegyűjtésében és feldolgozásában. Ebből a szempontból kiemelendő az a szolgálat, amely akár a többségi, akár a kisebbségi társadalomban az oktatás területén zajlik. Tehát nem csak arról van szó, hogy az egyház a cigánypasztoráció jóvoltából hozzájárulhat a hátrányos társadalmi helyzetben lévők oktatáson keresztüli felemelkedéséhez, hanem arról is, hogy az elő́téletekkel élők körében csökkentheti az előítéleteket. Lényeges tevékenységről van szó, hiszen ahogy az Allportnál is olvasható, a fokozatok eszkalálódása során már a legelső fokozat esetében közbeléphet az egyház (az előítéletesség fokozatait Allport a következőképpen állítja sorba: szóbeli előítéletesség, elkerülés, hátrányos megkülönböztetés, testi erőszak, kiirtás). Ha nem is szükségszerű ezeknek a fokozatoknak a megjelenése, azt azonban állíthatjuk, hogy egy alacsonyabb fokozat megjelenése előkészítheti és ezzel könnyebbé is teheti a magasabb fokozat megjelenését. Allport óta szinte evidencia a szociálpszichológiában, hogy az előítéletek kialakulása a kategorizációra vezethető vissza. Allport amellett érvel, hogy a kategorizáció folyamata nélkül az emberi elme képtelen lenne a gondolkodásra. Véleménye szerint a folyamat legalább öt fontos tulajdonsággal rendelkezik (Allport 1977). Talán a legfontosabb ezek közül, hogy „napi életünk alkalmazkodási folyamatait szabályozó nagyobb osztályok és csoportosítási szempontok képződnek." (Allport 1977: 53). Egyfelől ezek a kategóriák teszik lehetővé, hogy egyáltalán gondolkodjunk, hogy eligazodjunk a világban. Az „alkalmazkodás” azonban ennél többet is jelent. Allaport arra utal, hogy a kategóriák kifejezetten irányítják cselekvéseinket. A kategóriák Allport szerint tartalmazzák az „igazság szikráját”. A kategóriák ezekben az esetekben a tapasztalatból származnak. Ahogy fogalmaz: „Etnikai kategóriáink némelyike ésszerű. Valószínű például, hogy egy négernek sötétbarna a bőre (jóllehet ez nincs mindig így)." (Allport: 56) Más kategóriák viszont nem a tapasztalaton alapulnak. Ezek a kategóriák többnyire ésszerűtlenek. „Azt mondhatjuk, hogy az irracionális kategóriák ugyanolyan könnyen jönnek létre, mint

\footnotetext{
${ }^{9}$ Lásd Ferenc pápa, ill. VI. Pál előbbiekben elemzett gondolatait.
} 


\section{TEMATIKUS TANULMÁNYOK - Társadalmi mobilitás és segítői tevékenység}

az ésszerűek. Valójában az irracionális kategóriák valószínűleg még könnyebben jönnek létre, mivel az erős érzések a szivacshoz hasonló módon múködnek." (Allport 1977: 57) Lényeges kiemelnünk a kísérleti szociálpszichológia ide vonatkozó eredményei közül Tajfel és Wilkes 1963-as kísérletét. Csepeli (1997) megfogalmazása szerint Tajfel és Wilkes hipotézise a következő volt. „Tajfel és Wilkes (1963) kísérlete bizonyította be, hogy a kategorizáció nem szakadhat el a kategorizált ingerek valóságos tulajdonságaitól. A kísérlet hipotézise szerint, amikor a természeti valóságból vett ingersorozatra úgy alkalmazunk egy osztályozási rendszert, hogy az ingersorozat egyik része objektív tulajdonsága folytán az egyik osztályba, míg az ingersorozat másik része a másik osztályba tartozik, az egyes osztályokba sorolt ingerek észlelése az osztályba sorolás ténye által meghatározott módon fog alakulni, szemben azzal a helyzettel, amikor nem alkalmazunk osztályozást. A hipotézisben arra is utaltak, hogy az osztályba sorolás ítéleteket befolyásoló hatása elmarad, ha az ingerek valamely objektív tulajdonsága nincs összefüggésben az alkalmazott osztályozási rendszerrel." (Csepeli 1997: 462) Tajfel és Wilkes (1963) a kísérleti személyeknek egészen egyszerű ingereket, mégpedig vonalakat mutogattak. A kísérleti személyek feladata az volt, hogy becsüljék meg ezeknek a vonalaknak a hosszát. A vonalakat hol kategorizálva (egyszerűen „A”, ill. „B” betűket írtak alájuk), hol kategorizálás nélkül mutatták meg. A kísérlet eredményeként megállapítható volt, hogy a kísérleti személyek a vonalak egymáshoz képesti hosszát akkor becsülték meg pontosabban, ha a vonalak hosszúsága és a kategorizálás között kapcsolat volt (azaz a rövidebb vonalakat rendre az „A”, míg a hosszabb vonalakat rendre a „B” kategóriába sorolva mutatták meg). A kísérlet eredményeként egyértelműen bizonyítottá vált, hogy a kategorizáció felerősíti az amúgy is meglévő különbségeket. A kísérleti szociálpszichológia kifejezetten olyan terület, ahol a kutató aktív résztvevője a folyamatoknak, a folyamatok kifejezetten az előre megtervezett forgatókönyv mentén zajlanak. Ezen a ponton a cigánypasztoráció szempontjából nem a liturgiával való hasonlóságot emelném ki, sokkal inkább az aktivitást.

\section{Összegzés}

Megállapítható tehát, hogy az ember és ember közötti alá-fölé rendelő különbségtétel, az emberi lét legmélyebben beágyazott jellemzője. Ahogyan az imént megidézett Allport (1977) gondolatait idézve világosan láthatóvá vált, hogy ha az ingerek alapján történő kategorizáció mozgásba lendül, akkor a kategorizáció olyan területekre is kiterjedhet, amelyek nem a „valóságos ingerek” alá tartoznak. A cigánypasztoráció esetében olyan társadalompedagógiai folyamatról is szó van, amelynek során tudatosan hívják fel a közösség tagjainak figyelmét arra, hogy mennyire hasonlatosak egymáshoz. Ezzel is csökkentik a konfliktuspotenciált a közösségen belül. Így a kategorizáció nyomán létrejövő rasszizmus megelőzését tudatosan kezdik el. Társas, 


\section{TEMATIKUS TANULMÁNYOK - Társadalmi mobilitás és segítői tevékenység}

társadalmi viszonyrendszerben a kategorizáció elsősorban a saját és a másik csoport közötti különbségtétel során jelenik meg. Természetesen nem könnyű meghatározni, hogy pontosan mit is jelent a saját csoport. Ezért Allport a következőt javasolja. „Széles értelemben véve úgy határozzuk meg a saját csoportot, mint olyan személyek együttesét, akik azonos jelentéssel használják a »mi« személyes névmást." (Allport 1977: 77) Allport elsősorban nem vagy nem csak nyelvi kérdésre utal, ezért is használja az eredeti szövegben a „term” szót. A „mi” sokkal inkább valamiféle jelentésteli egész, ami olyan elemekből áll, amelyek hasonlítanak egymáshoz. A „mi” ennek a hasonlóságnak a hangsúlyozását jelenti. A cigánypasztoráció esetében ennek a hasonlóságnak a hangsúlyozásáról van szó többnyire anélkül, hogy megjelenne benne a „másik” csoporthoz képesti elkülönülés hangsúlyozása. Sőt, kifejezetten egy inkluzív „mi”-ről van szó, olyanról, amelynek tagja lehet, aki tagja akar lenni. ${ }^{10}$ Itt voltaképpen toleranciáról, a cigányok és a nem cigányok közötti együttélésről van szó. A saját csoport léte feltételezi a másik csoport létét is, hiszen saját csoportnak csak akkor van értelme, ha van másik csoport is. A másik csoporttal kapcsolatos ellenszenv azonban Allport szerint nem szükségszerű (miközben a társas, társadalmi világban gyakran tapasztaljuk, hogy ellentét van a csoportok között). Allport szerint „saját csoportunkat ugyan csak más csoportokkal összevetve tudjuk felismerni, a saját csoport azonban pszichológiai értelemben elsődleges. Bennünk, általuk és sokszor értük élünk. Más csoportokkal szemben érzett gyúlölködésünk megerősítheti hovatartozási érzéseinket, de ez nem szükségszerü.” (Allport 1977: 85) Majd a következő bekezdésben úgy folytatja, hogy „mivel az elfogultság és az etnocentrizmus létfontosságú életben maradásunk és önértékelésünk miatt, hajlamosak vagyunk arra, hogy saját csoportunkkal szemben elfogultak legyünk, és a többi fölé helyezzük." Állításom az, hogy a kategorizációhoz kapcsolódó minősítést, illetve a minősítésből adódó negatív következményeket az egyház képes kezelni. Tekintettel arra, amit a korábban megidézett egyházfók, pápák is kinyilatkoztattak, valamint a Bibliában foglaltakra, természetes terep az egyház számára a cigánypasztoráció. Mind a toleranciaépítés, mind a társadalompedagógia, mind a cigány-nem cigány együttélés, mind a konfliktuskezelés szempontjaiból. Sőt kifejezetten hangsúlyozni szeretném a hit megbékélést és megnyugvást is elősegítő funkcióját (és itt gondoljunk csak egy pillanatra újra az identitás során rámutatottakra, a bizonytalanságra, illetve a marginális helyzetben élők pszichoszociális identitásának problémáira). Ennek két formájára is utalok. Egyfelől arra, amit a békességet hirdető evangéliumban áll, amelynek teológiai elemzésétől ezúttal eltekintek. Kifejezetten olyan üzenetről van szó, amely-

${ }^{10}$ Ezen a helyen el kell tekintenünk a világrendszer szintű vallási konfliktusok részletesebb elemzésétől. Nyilvánvalóan nem lehetünk vakok azokra a civilizációk közötti konfliktusokra, amelyek vallási ellentétekből származnak (Huntigton 1993). A cigánypasztoráció azonban ennél jóval lokálisabb, elsősorban Európára vonatkozó tevékenység. Így aztán - legalábbis egyelőre - a Huntington-féle megfigyelés is kevésbé jellemző a térségre. 


\section{TEMATIKUS TANULMÁNYOK - Társadalmi mobilitás és segítői tevékenység}

nek fókuszában a megbékélés, a béke eljövetele áll. Másfelől a közösség szerepére utalok. Azaz a közösséghez tartozás adhat olyan megnyugvást, amely kifejezetten hasznos azokban az esetekben, amikor valaki, vagy maga a közösség traumát élt át (Herman 2003). Egyfelől rendkívül fontos, hogy a közösség segít a trauma túlélőjének. „A traumatúlélő és a közösség közötti megbomlott kapcsolat helyreállítása két dologtól függ: a traumatikus esemény nyilvános elismerésétől és valamiféle közösségi cselekvéstől.” (Herman 2003: 91) Másfelől rendkívül lényeges a közösség gyógyító szerepe. „A csoportszolidaritás nemcsak a legjobb védelem a rettegés és a kétségbeesés ellen, hanem a traumatikus élmény leghatékonyabb ellenszere is. A trauma elszigetel, a csoport helyreállítja az összetartozás érzését. A trauma megaláz és stigmatizál, a csoport tanulságot tesz és megerősít. A trauma lealacsonyít, a csoport megdicsőít. A trauma elembertelenít, a csoport újra emberré tesz." (Herman 2003: 275) A különböző területeken, gyakran halmozottan hátrányos helyzetben élő cigány emberek pedig bőven éltek és élnek át traumákat. Sőt, egy kutatás szerint amely nem kifejezetten cigányokról szól - egyértelműen bebizonyosodott, hogy a kulturális és gazdasági értelemben vett szegénység szorosan összefügg a traumatikus gyermekkorral (Fekete - Prazsák 2014). Az egyház cigánypasztorációs szolgálatát a nemzetközi intézményrendszere szempontjából is lényeges kiemelnünk. Egyértelmű, hogy a romákkal kapcsolatos negatív diszkrimináció kezelése nem maradhat országhatárokon belül. Például a Kárpát-medencében kifejezetten jól látható ez, ahol Szlovákiában, Magyarországon, Ukrajnában, Romániában, Szerbiában (és noha nem Kárpát-medence, de azért ide kell sorolnunk Macedóniát, illetve Bulgáriát is). Teljesen egyértelmű, hogy ezeken a helyeken együttes fellépésre van szükség (Prazsák 2018). Ezt társadalompolitikai szempontból kifejezetten támogatni tudja és támogatja is az Európai Unió. Az egyház nemzetközi intézményrendszere kifejezetten hasznos lehet a negatív diszkrimináció elleni összehangolt nemzetközi fellépés, a tolerancia megteremtése szempontjából. Ebben a tanulmányban arra kívántam rámutatni - hogy az egyház cigánypasztorációs küldetése és a társadalomtudományos, szociálpszichológiai ismeretek összefüggenek egymással. Mind a kialakult helyzetek, mind azok kezelésének céljai - és esetenként gyakorlatai - is hasonló megközelítés alá esnek. A tolerancia megteremtése, a társadalompedagógia, a konfliktus redukció és a konfliktusmenedzsment olyan fogalmak és tevékenységek, amelyekkel mind a tudomány, mind a (társadalom)politika, mind az egyház természeténél fogva foglalkozik. A cigánypasztoráció tehát az egyház szakpasztorációs tevékenysége, amely a bibliai tanításoknak megfelelően cigányok körében végzett szolgálati tevékenység, fókuszában mind az evangéliumok hirdetésével, mind szociálpolitikai, társadalompedagógiai tevékenységekkel. A társadalmi konfliktusok megelőzése és kezelése is a szakpasztorációs szolgálat része. Ezen a ponton a cigánypasztoráció nyilvánvalóan érintkezik a többségi társadalom körében végzett szolgálattal is, azzal együtt, hogy a cigánypasztoráció elsősorban cigányok körében végzett tevékenység. 


\section{TEMATIKUS TANULMÁNYOK - Társadalmi mobilitás és segítői tevékenység}

E tanulmányban fontosnak tartottam, hogy tisztázzuk azokat a fogalomköröket, amelyek az egyház cigányok/romák körében indított missziójának alapját adják. Ezek közül a legfontosabbnak társtudományok által meghatározott fogalomkörök és eredmények mellett a pasztoráció meghatározását tartom. Bepillantást kaptunk a hazai egyházi tevékenység mellett az európai pasztoráció történetébe is. Arra is rá kívántam mutatni, hogy a cigánypasztoráció Magyarországon rendkívül lényeges össztársadalmi tevékenység, feladat. Áttekintettük a cigányokkal foglalkozó egyházi szervezeteket. Azokat, amelyek kifejezetten a romákkal kapcsolatos segítő, szociális tevékenységeket végeznek. A cigánypasztoráció segítségével olyan eszközt kap a társadalom, amellyel kezelhetőnek tűnnek a többségi és a kisebbségi társadalmak közötti konfliktusok. Számos feladatot nem vállalhat magára az egyház, azonban sok segítséget adhat mind szociális értelemben, mind a társadalmi megbékélés szempontjából.

\section{Irodalom}

2011. évi CLXXIX törvény a nemzetiségek jogairól, https://net.jogtar.hu/jogszabaly? docid=A1100179.TV (Utolsó letöltés: 2019. 05. 28.)

Allport, G. W. (1977): Az előítélet. Budapest, Gondolat Kiadó.

A II. Vatikáni Zsinat Dokumentumai 2000. Budapest, Szent István Társulat.

Bartha Cs. (2015) Nyelvi hátrány, avagy a cigány gyermekek oktatásának elmulasztott lehetőségei. In: Antalné Szabó Á. - Laczkó K. - Major É. - Raátz J. (szerk.): Szakpedagógiai körkép I. Anyanyelv- és irodalompedagógiai tanulmányok. Bölcsészet- és Múvészetpedagógiai Kiadványok (2). Budapest, Eötvös Loránd Tudományegyetem, 28-45.

Ceferino Ház (2010): Pápai Tanács üzenete a CCIT konferenciának - 2010 https://ceferino.hu/2010/08/06/vandorlok-es-utonlevok-papai-tanacsanak2010-es-konferenciajanak-zarodokumentuma/ (Utolsó letöltés: 2020. 04. 29.)

Ceferino Ház (2018): Kocsmából Közösségi ház. https://ceferino.hu/2018/10/16/ kocsmabol-kozossegi-haz/ (Utolsó letöltés: 2018. 11. 09).

Csepeli Gy. (1997): Szociálpszichológia. Budapest, Osiris Kiadó.

Fekete M. - Prazsák G. (2014): Kulturális kasztrendszer: Autonómia és közösségiség szerepe a fiatalok kulturális aktivitásában. In: Nagy Á. - Székely L. (szerk.): Másodkézből - Magyar Ifjúság 2012. Budapest, Kutatópont, 195-218.

Fraser A. (2006): A cigányok. Budapest, Osiris Kiadó.

Herman J. (2003): Trauma és gyógyulás. Az erőszak hatása a családon belüli bántalmazástól a politikai terrorig. Budapest, Háttér Kiadó.

Huntington, S. P. (1993): The Clash of Civilizations? Foreign Affairs, 3, 22-49. 


\section{TEMATIKUS TANULMÁNYOK - Társadalmi mobilitás és segítői tevékenység}

Il caso zingari, (2008): Leonardo International.

Kemény I. - Janky B. - Lengyel G. (2004): A magyarországi cigányság 1971-2003. Budapest, Gondolat - MTA Etnikai-nemzeti Kisebbségkutató Intézet.

Kemény I. - Janky B. (2003): A 2003. évi cigány felmérésről. Népesedési, nyelvhasználati és nemzetiségi adatok. Beszélő, 8(10): 64-77.

Kolozsi Á. (2019): Ferenc pápa bocsánatot kért a cigányoktól Erdélyben. https://index.hu/kulfold/2019/06/02/ferenc_papa_ciganyok_romania_erdely_balazsfa/ (Utolsó letöltés: 2019. 05.29.)

Krómer I. (2007): Hajtsátok uralmatok alá - de hogyan? http://www.tavlatok.hu/ 75/75magyar_figyelo.htm (Utolsó letöltés: 2019. 04. 07.)

KSH (2014): Népszámlálás 2011. Budapest, Központi Statisztikai Hivatal, 14-66.

Lakatos Sz. (2015): A romani nyelv a kutatás és oktatás tükrében. In: Orsós A. (szerk.): A romológia alapjai. Pécs, PTE-BTK Neveléstudományi Intézet Romológiai és Nevelésszociológiai Tanszék, Wlislocki Henrik Szakkollégium, 181-208.

Magyar Kurír (2015): Magyar zarándokokat is fogadott a pápa az európai cigánytalálkozón. https://www.magyarkurirhu/hirek/europa-minden-reszebol-erkeztekcigany-zarandokok-ferenc-papahoz (Utolsó letöltés: 2019. 05. 29.)

Nietzsche, F. (1992): A nem-morálisan fölfogott igazságról és hazugságról. Athenaeum, 3(1): 3-15.

Orsós A. (2015): A Beás Nyelv. In: Orsós A. (szerk.): A romológia alapjai. Pécs, PTEBTK Neveléstudományi Intézet Romológiai és Nevelésszociológiai Tanszék, Wlislocki Henrik Szakkollégium, 151-180.

Pataki F. (1987): Identitás, személyiség, társadalom. Az identitáselmélet vitatott kérdései. Budapest, Akadémiai Kiadó.

RomNet, (2004): A romák európai fóruma.

http://www.romnet.hu/hirek/2004/12/17/a_romak_europai_foruma (Utolsó letöltés: 2020. 04.30.)

Somogyi V. (2018): Ferenc pápa a xenofóbia, a rasszizmus és a populizmus veszélyeire figyelmeztetett. https://www.vaticannews.va/hu/papa/news/2018-09/ ferenc-papa-a-xenofobiarol-a-rasszizmusrol-es-a-nacionalizmusro.html (Utolsó letöltés: 2019. 01.04.)

Szentírás (2001): Budapest, Szent Jeromos Katolikus Bibliatársulat - Szent István Társulat az Apostoli Szentszék Könyvkiadója. (Mt. 28:17, Mt. 5,1-12)

tzs (2016): Esztergomban tartották a nemzetközi cigánypasztorációs konferenciát. Magyar Kurír. április 10. www.magyarkurir.hu/hazai/esztergomban-tartottak-nemzetkozi-ciganypasztoracios-konferenciat (Utolsó letöltés: 2016. 04. 12.) 